(i-COME'20)

INTERNATIONAL CONFERENCE ON COMMUNICATION AND MEDIA 2020

\title{
THE IMPACT OF BRAND DEVELOPMENT STRATEGY ON BRAND EQUITY
}

\author{
Rohana Mijan (a)*, Shuhaida Md Noor (b), Noor Aziah Abdullah (c) \\ *Corresponding author
}

(a) School of Multimedia Technology and Communication (SMMTC), UUM College of Arts and Sciences, Univeristi Utara Malaysia, 06010 UUM Sintok, Kedah Darul Aman, rohana.mijan@uum.edu.my (b) School of Communication, Universiti Sains Malaysia,11800 Pulau Pinang, shuhaida@usm.m. (c) School of Multimedia Technology and Communication (SMMTC), UUM College of Arts and Sciences, Univeristi Utara Malaysia, 06010 UUM Sintok, Kedah Darul Aman, nooraziah@uum.edu.my

\begin{abstract}
This purpose of this study is to explore the impact of brand development strategy-based resources on brand equity performance of Malaysian Small and Medium-sized Enterprises (SMEs) where SMEs are often associated with financial measurements and short-term oriented performance. This qualitative study applied in-depth interview methods with the company representatives of 10 brand-oriented SMEs in Malaysia. Thematic analysis was utilised to reveal the themes, especially the prominent ones pertaining to brand equity performance. The study found that the brand development strategies comprises of branding and communication strategies have influenced a positive impact on brand equity performance. The effectiveness of brand equity translated unconsciously since the company priority measurement is still the financial performance. This study focussing in the brand development strategies in the context of Malaysian. Therefore, the future study proposed to adopt a broader perspective by specifying the measurement of brand development strategy in larger sample sizes. The research provides new insights into creating awareness and understanding of the importance of brand equity in measuring the actual performance of the brand development strategy.
\end{abstract}

2357-1330 (C) 2021 Published by European Publisher.

Keywords: Branding, brand orientation, brand equity, small and medium-sized enterprises 


\section{Introduction}

Brand development is an effort by companies to develop their resources to formulate brand development strategies to improve brand performance. It is essential to create a competitive brand in the market because it can form loyal customers and in turn contribute to the economic growth of the company (Aaker, 1996; Kim \& Kim, 2005). The actual measurement, like brand equity, will translate the natural performance of the brand development strategy. However, most SMEs have ignored the significance of brand equity to the company growth. The financial measurement is the leading benchmark to estimate the future of brand development strategy (Maznah \& Mohd Noor, 2010). This is in contrast to brand-oriented SMEs that utilised the brand equity performance to determine their brand development strategy.

A brand-oriented SMEs is one that has an awareness of the importance of branding (Bridson et al., 2003; Hirnoven \& Laukkanen, 2013), unlike typical SMEs. Branding awareness is translated through the exploration of company resources such as tangible resources including brand uniqueness, product differences and human resources. In contrast, intangible resources involve brand symbolism, culture, internal communication, innovation and social capital in creating competitive strategies for brand equity (Bridson \& Evans, 2004).

These SMEs develops a brand from an inside-out approach to obtain information to build the brand (Urde, 1999). All levels of management and employees in a company are involved in branding activities (Baumgarth, 2010; Gromark \& Melin, 2011). Brand communication is also evidence of strategy-based resource as companies build effective communication internally before delivering messages to customers and getting information from the market (Ewing \& Napoli, 2005; Gromark \& Melin, 2011; Hankinson, 2001). The strategies utilise the advantages of brand uniqueness in branding strategies (Hankinson, 2001; Urde, 1999) and staff behaviour (Baumgarth, 2010; Ewing \& Napoli, 2005). Through this strategic communication, companies are able to obtain market information and adapt to market changes as well as focus on the internal resources of the company that allows the developed brand to have brand equity in the market.

Brand equity is the process of creating a value-added brand based on the advantages of the company's products and services through the positioning of the brand name to build relationships between brand and customers (Aaker, 1996; Atilgan et al., 2005). However, the advantages of products and services are not only linked to the brand name, but they can also be connected to the advantages of other tangible and intangible resources. There are generally two perspectives on brand equity (Kamakura \& Russell, 1993; Noor et al., 2011) which are financial-based brand equity (Ailawadi et al., 2003; Feldwick, 1996; Muyimba, 2009) and customer-based brand equity (Aaker, 2003; Keller, 2008). Measurements by Aaker (1996) are more focused on a company's internal measurements than Keller (2008) that focus on customers in the market as a whole and Anderson and Eshima (2011) on financial measurements.

Aaker (1996) focuses on customers as a key indicator in measuring a company's brand equity. This signifies that customers determine the true success of a brand in the market. Wang and Finn (2012) and Aaker (1996) provide a more in-depth understanding by relating customer evaluation of the brand based on the company's ability to meet customer preferences. Brand information that meets customer preferences will influence perceptions and behaviours to be loyal to the brand, and these actions give a 
positive impact on brand equity. Measurement of brand equity from a customer's perspective reflects a brand's competitiveness in the market and the company's ability to meet customer preferences (Urde, 1999; Wong \& Merrilees, 2005). There are several dimensions to measure brand equity value of a company. First, the brand awareness refers to a customer's memory of a brand in terms of the ability to recognise and remember the nature of the product (Hirnoven \& Laukkanen, 2012; Keller, 1993). Brand awareness is important since familiarity and partiality to certain brands will in turn influence a customer's purchasing decisions and as Atilgan et al. (2005) observed, a high level of brand recall reflects the power and value of a particular brand in the market.

Second, brand association refer to the link between a customer's memory process of the brand (Aaker, 1991; Wang \& Finn, 2012). The more experiences with a brand, the better the brand information is obtained. Brand information that is close to the customer and allows them to differentiate competitive brands will help process the information to make a purchase. The positive information gathering associated with the brand becomes a strong reason to continue the purchasing process (Aaker, 1991; Tuominen, 1999; Wang \& Finn, 2012; Yoo et al., 2000). The information helps companies to expand their brand networking (Aaker, 1991).

Third, a perceived quality that represents the customer's perception of the overall quality or superiority of a product or service offered compared to competitors (Aaker 1991; Wang \& Finn, 2012; Zeithaml, 1988). Customer acceptance of brand quality allows companies to set premium prices and this action helps to increase company profits. A positive assessment of this level of quality allows companies to use brand names to expand their brand network (Aaker 1991; Wang \& Finn, 2012).

Forth, brand loyalty refers to the deep commitment shown by a customer to repeat the purchase of a product or service that is a consistent preference in the future even in different market conditions and influences from other brands (Oliver, 1997; Tuominen, 1999; Urde, 1994). Customer loyalty is measured by the tendency of customers to buy the same brand and delay the purchase if the brand is still not on the market (Wong \& Merrilees, 2007). Customer loyalty is important for companies to gain the trust of new customers (Hirnoven \& Laukkanen, 2012), reduce marketing costs, expand businesses, attract new customers and be able to reduce competitive pressure (Aaker, 1991).

These dimensions are the process of customer acceptance of the brand, starting from awareness up to brand loyalty. Cumulative positive of these dimensions will affect the effectiveness of brand equity in the market. Aaker (1996) measures the effectiveness of branding from a company perspective. The measurement based on a company's capability will translate the natural performance of the brand development strategies undertaken and that will give a benchmark for the upcoming brand planning.

The findings of this study are important to provide a clear of the meaningful impact of brand development strategies on brand equity performance. This article discusses the literature review on branding in brand-oriented SMEs and research theory. Next, the method is discussed, and the findings of the study, discussion and conclusions are displayed.

\section{Problem Statement}

The actual measurement of brand development is essential to guide the company in the long-term brand planning. However, SMEs have often ignored the actual measurements for brand development 
strategies, including Malaysia (Fauziah et al., 2012; SME Annual Report, 2014/2015). The lack of branding awareness prompting them to measure brand development strategies based on short-term measures such as sales volume, costs and company margins (Ewing et al., 2001; Maznah \& Mohd Noor, 2010) while the impact of branding activities takes a long time to enjoy (Guiling \& Xiaojuan, 2006; Krake, 2005).

This is in contrast to brand-oriented SMEs that assess the actual impact of a brand's position in the market based on brand equity. This measurement is important because it assesses the substantial competitiveness of a brand in a market (Urde, 1999; Wong \& Merrilees, 2005).

\section{Research Questions}

What are the impacts of brand development strategies carried out by the brand-oriented company on the brand equity performance?

\section{Purpose of the Study}

The purpose of this study is to find out the impacts of brand development strategies carried out by the brand-oriented company?

\section{Research Methods}

This study used in-depth interview methods with brand-oriented SMEs entrepreneurs. Samples were taken from recognised bodies such as SMEs Brand Laureate (2012), Trusted Brand Award (2012), Malaysian's Most Valuable Brands (2012) and Putra Brand Awards (2013). Entrepreneurs were participants who took part in the interview session because of decision-making autonomy (Creswell, 2007; Merriam, 1990). Interview questions revolved around company branding practices. Interview data were analysed by themes and categories to link to the main themes (Burnard, 1991).

\section{Findings}

The data showed that the type of measurement used to measure the effectiveness of the strategy was quite different for each company. What is significant is that the companies focused on financial measurement in measuring the brand development strategy carried out and did not use standard equity measurements. However, based on respondents' descriptions, the companies have measured the brand development strategy based on the four dimensions of brand equity. Overall, strategy development has a positive impact on the companies' growth such as facilitating the companies to gain new customers, expanding the brand network, saving the companies' marketing costs, increasing the company's finances and gaining recognition from the companies' stakeholders.

Most respondents stated that brand equity allows them to get new customers easily. For example, a company B respondent said:

Usually, the company projects we get from many good friends and people we know. When we give good services to customers, then the next project they will share with us. That is how we grow our brand. 
Data analysis also showed that brand equity made it easier for companies B, C, D, E, F, H, I and J to expand their brand network. According to company respondent I:

We are able to manage the hotel well. For example, the Indonesian government gave us a hotel in Lombok as well as in Arab. They come for site visits and confident with the product, quality and service. So that is why they gave us the project.

According to the respondents of companies B, C, D, E, H, I and J, brand equity allows their brand to be known in the market, reduces marketing activities and their marketing costs. Respondent company C said:

The communication technology used to call the crowd. To us, close customers are already familiar with our brand. So they already know about our brand. So, we do not need to run promotions intensively.

Brand equity also improves the financial performance of the company. Respondents also assessed the impact of brand equity based on brand recognition obtained from stakeholders such as employees, brand recognition bodies, financial institutions and investors. Respondent from the company A said:

We have awards like Teraju, National Mark, SMEs Award. So our brand is strong. Our employees are also confident in the brand. So our staff is very loyal in Kota Bharu, for example. We do not face employee problems. So we are in harmony in developing the brand...

It was found that the majority of respondents informed that they had the pleasure to gain the impact of brand equity since the financial performance curving increasingly as well as a decreased marketing cost, gained loyal employees and being awarded. The description clearly shows their ability in developing a brand based on their resources.

The development of a brand strategy based on a company's resources gave great success to the company (Mijan et al., 2020). The proof is that respondents measure the strategies in-depth and comprehensively where they not only evaluated based on financial returns but also the recognitions given by their stakeholders. The companies measure the effectiveness of brand development strategy based on financial performance and it is a periodic measure of the company. This is in line with the statement of Maznah and Mohd Noor (2010) who stated that SMEs are indeed concerned with short-term measures in evaluating brand development strategies. It is a contrast to the study of Urde (1999) and Wong and Merrilees (2005) who reported that brand-oriented SMEs measure their brand based on brand equity such as brand awareness and brand loyalty. This study shows that companies value their brand relationships with customers, but they do not have a specific measurement to evaluate the brand's position in the market. The lack of brand equity measurement leads companies to focus on their financial performance and stakeholder recognition.

The findings of this study are also different from previous results. For example, Hirnoven and Laukkanen (2013) noted that brand equity helps companies gain new customers through a positive image. However, this study found that new customers were gained through recommendations from customers who have dealt with the companies. Wong and Merrilees (2007) mentioned that communication strategies provide awareness to customers and increase brand loyalty. Loyal customers enable companies to reduce costs in implementing their marketing strategy to gain new customers.

Interestingly, this study also found that the use of social media as one of the communication strategies employed by companies succeeded in enhancing customers' awareness of a brand's superiority 
but less effective in creating customer loyalty. However, verbal communication (word-of-mouth) among existing loyal customers are able to influence other customers to buy the brand. This, in turn, can reduce marketing costs as word of mouth becomes a brand promotion agent indirectly for the company. In short, the contribution of loyal customers can reduce the financial burden of a company from conducting largescale brand publicity.

Brand equity does indeed improve financial performance through customer satisfaction and loyalty (Park \& Kim, 2013) and it is quite different from the findings of Hirnoven and Laukkanen (2012) who showed that brand loyalty enables companies to offer premium prices. The high price increases a company's sales and financial position. The data shows that premium prices do not directly contribute to the financial improvement of the company because all respondents set premium prices to attract customers to know the brand and create differentiation in the market. Unparallel with Hirnoven dan Laukkanen (2012) study mention the price premium has increased the companies' profit.

The study also found that brand-oriented SMEs also measure brand equity based on brand recognition obtained from stakeholders such as employees, brand recognition bodies, financial institutions and investors. Interestingly, SMEs take into account the effectiveness of their brand development strategies from a broader perspective not only on financial measurement and customers but also on other company stakeholders. This recognition also reflects the effectiveness of the brand equity impact on the brand development strategy undertaken. This is because the award given by these stakeholders is based on the strong position of the brand in the market. For SMEs, such recognition becomes a steppingstone for them to grow their brand.

\section{Conclusion}

In conclusion, brand-oriented SMEs overcome the lack of resources by focusing on their internal resources. Companies formulate strategies using an inside-out approach. The formation of a brand development strategy from internal allows the creation of competitive brand strategies that are difficult to emulate by competitors. It enables brand differences to be maintained in the market. It was also found that brand-oriented SMEs evaluate strategies based on three dimensions, namely brand equity, financial performance and stakeholder recognition as they develop their brand from diverse resources. The impact of brand development strategy carried out is the result of brand equity and it also empowers the existing brand equity. The more comprehensive measurement provides a guideline to SMEs to evaluate their brand equity in various measurements.

The measurement of brand development strategies in this study contributes to the body of knowledge. Previous studies have shown that the relevant measurements for the strategy-based resource rely on the company's financial measurement, internal process efficiency and market measurements. However, this study also found that there are other measurements taken to evaluate the effectiveness of the strategy. Based on the brand orientation approach, companies tend to measure brand development strategies from various angles as they develop their brand by using each of their strategic brand resources. This is reflective of the type of measurement in evaluating the effectiveness of brand development strategy. 
Findings from this study also signify that the strategy-based resources have affected the brand equity's dimensions that accumulate formed the brand equity in the market. The outstanding performance of brand equity to the companies' brand development has undoubtedly spurred an awareness among entrepreneurs on the importance of brand equity in representing the actual performance of a brand and planning the upcoming strategy. The contribution has opened the eyes of entrepreneurs to develop their resources to create brand equity in the market.

\section{References}

Aaker, D. (2003). The power brand of the differentiator, MIT Sloan Management Review, 45(1).

Aaker, D. A. (1996). Measuring brand equity across products and markets, California Management Review, 38(3), 102-120.

Aaker, D. A. (1991). What is brand equity? Managing brand equity: Capitalizing on the value of a brand name. The Free Press.

Ailawadi, K. L., Donald, R. L., \& Scott, A. N. (2003). Revenue Premium as an Outcome Measure of Brand Equity. Journal of Marketing, 67, 1-17.

Anderson, B. S., \& Eshima, Y. (2011). The influence of firm age and intangible resources on the relationship between entrepreneurial orientation and firm growth among Japanese SMEs, Journal of Bussiness Venturing. https://doi.org/10.1016/j.jbusvent.2011.10.001

Atilgan, E., Aksoy, S., \& Akinci, S. (2005). Determinants of the brand equity A verification approach in the beverage industry in Turkey, Marketing Intelligence \& Planning, 23(3), 237-248.

Baumgarth, C. (2010). Living the brand: Brand orientation in the business-to-business sector, European Journal of Marketing, 44(5), 653 - 671.

Bridson, K., Evans, J., \& Mavondo, F. (2003). The role of brand orientation in explaining retail offer advantage. Prosiding di 12th European Association for Education and Research in Commercial Distribution (EAERCD), ESCPEAP/CERIDICE, (hal. 1-12), Perancis.

Bridson, K., \& Evans, J. (2004). The secret to a fashion advantage is brand orientation, International Journal of Retail and Distribution Management, 32(8), 403-411.

Burnard, P. (1991). A method of analysing interview transcripts in qualitative research, Nurse Education Today, 11, 461-466.

Creswell, J. W. (2007). Qualitative Inquiry and Research Design. USA: Sage Publications.

Ewing, M., Napoli, J., \& Pitt, L. (2001). Managing Southeast Asian brands in the global economy, Business Horizons, 44(3), 52-58.

Ewing, M. T., \& Napoli, J. (2005). Developing and validating a multidimensional nonprofit brand orientation scale, Journal of Business Research, 58, 841-853.

Fauziah, S. A., Rosmini, O., Siti Zaleha, A. R., \& Muslim, A. (2012). Leadership branding for sustainable customer engagement, International Journal of Economics and Management Engineering, 6(2), 209-216. https://doi.org/10.5281/zenodo.1085623

Feldwick, P. (1996). What is brand equity anyway, and how do you measure it? Journal of the Market Research Society, 38(2), 85-104.

Gromark, J., \& Melin, F. (2011). The underlying dimensions of brand orientation and its impact on financial performance, Journal of Brand Management, 18(6), 394-410.

Guiling, L., \& Xiaojuan, Z. (2006). The brand management status and development research of SME in $\begin{array}{llll}\text { China. } & 10 & \text { April } & 2012\end{array}$ http://www.seiofbluemountain.com/upload/product/200911/2006zxqyhy11a14.pdf.

Hankinson, P. (2001). Brand orientation in the charity sector: A framework for discussion and research, International Journal of Nonprofit and Voluntary Sector Marketing, 6(3).

Hirvonen, S., \& Laukkanen, T. (2013). Brand orientation in small firms: an empirical test of the impact on brand performance, Journal of Strategic Marketing, 22(1), 41-58. https://doi.org/10.1080/0965254X.2013.819372 
Hirnoven, S., \& Laukkanen, T. (2012). How Brand Orientation Contributes to Business Growth in SMEs? Prosiding di Australian \& New Zealand Marketing Academy (ANZMAC), (hal. 1-7), Australian \& New Zealand.

Kamakura, W. A., \& Russell, G. J. (1993). Measuring brand value with scanner data. International Journal of Research in Marketing, 10, 9-22.

Keller, K. L. (2008). Strategic Brand Management (3rd ed.). Pearson Prentice-Hall.

Keller, K. L. (1993). Conceptualizing, measuring, and managing customer-based brand equity, Journal of Marketing, 57(1).

Krake, F. B. G. J. M. (2005). Successful brand management in SMEs: A new theory and practical hints, Journal of Product and Brand Management, 14(4), 228-238.

Kim, H.-B., \& Kim, W. G. (2005). The relationship between brand equity and firms' performance in luxury hotels and chain restaurants, Tourism Management, 26(2005), 549-560.

Malaysian's Most Valuable Brands (2012). Retrieved from https://aaaa.org.my/

Maznah, W. O., \& Mohd Noor, M. A. (2010). Managing brand equity among Langkawi's (SMEs) independent hoteliers, International Journal of Marketing Studies, 2(1).

Merriam, S. B. (1990). Case Study Research in Education. Jossey-Bass.

Mijan, R., Noor, S., \& Jaafar, M. (2020). Exploring strategic branding resources for small and mediumsized brand-oriented companies, SEARCH Journal of Media and Communication Research, 12(1), $29-45$

Muyimba, A. (2009). Brand equity and SME performance in Uganda, Makerere University Business School. Diakses $\quad 12 \quad$ pada $\quad 12$ April 2013 daripada https://docs.google.com/viewer?a=v\&pid=sites\&srcid=ZGVmYXVsdGRvbWF pbnxyZXN1YXJjaGFuZGV4cGxvcmV8Z3g6 NGExYzY0NTUyYjI1M2I3ZA

Noor, S., Styles, C., \& Cowley, E. (2011). "Brand Equity", dalam Perspectives in Brand Management. Victoria: Tilde University Press.

Oliver, C. (1997). Sustainable competitive advantage combining institutional and resource based views, Strategic Management Journal, 18(9), 697-713.

Park, S. I., \& Kim, M. J. (2013). Does brand orientation matter? An empirical study in Korean SMEs, Asia Marketing Journal, 14(4), 117-142.

Putra Brand Awards (2013). Retrieved from https://aaaa.org.my/

SMEs Brand Laureate (2012). Retrieved from https:/www.thebrandlaureate.com/smes-bestbrandsaward/smes-bestbrands-award-2012/

SMEs Corporation of Malaysia. SMEs Annual Report 2014/2015. Published by Perbadanan Perusahaan Kecil \& Sederhana, Kuala Lumpur.

Trusted Brand Award (2012). Retrieved from https://www.trustedbrands.asia/malaysia/

Tuominen, P. (1999). Managing Brand Equity. Retrieved from http://1ta.hse.fi/1999/1/lta_1999_01_a4.pdf

Urde, M. (1999). Brand orientation: A Mindset for building brands into strategic resources, Journal of Marketing Management, 15(1-3), 117-133.

Urde, M. (1994). Brand Orientation - A Strategy for Survival, Journal of Consumer Marketing, 11(3), 1832.

Wang, L., \& Finn, A. (2012). Measuring consumer-based brand equity across brand portfolios: Manyfacet Item Response Theory perspective. Journal of Targeting, Measurement and Analysis for Marketing 20, 254 - 260. https://doi.org/10.1057/jt.2012.20

Wong, H. Y., \& Merrilees, B. (2007). Closing the marketing strategy to performance gap: The role of brand orientation, Journal of Strategic Marketing, 15(5), 387-402.

Wong, H. Y., \& Merrilees, B. (2005). A Brand orientation typology for SMEs: A case research approach, Journal of Product and Brand Management, 14(3), 155-162. https://doi.org/10.1108/10610420510601021

Yoo, B., Donthu, N., \& Lee, S. (2000). An examination of selected marketing mix elements and brand equity. Journal of the Academy of Marketing Science, 28, 195.

Zeithaml, V. A. (1988). Consumer perceptions of price, quality, and value: A means-end model and synthesis of evidence. Journal of Marketing, 52, 2-22. 